\title{
Educational Inequality and the Science of Diversity in Grutter: A Lesson for the Reparations Debate in the Age of Obama
}

\author{
Derrick Darby
}

Courts know today that statutes are to be viewed, not in isolation or in vacuo, as pronouncements of abstract principles for the guidance of an ideal community, but in the setting and the framework of present-day conditions, as revealed by the labors of economists and students of the social sciences in our own country and abroad. ${ }^{1}$

\section{INTRODUCTION}

More than five decades after Brown v. Board of Education, ${ }^{2}$ there remains a crisis of black student educational underachievement relative to white students in the United States. And this sobering fact may well have been at the forefront of President Barack Obama's mind during a presidential primary address in South Carolina when he remarked: "I think the reparations we need right here in South Carolina is investment, for example, in our schools." 3 He was certainly not suggesting that no blacks have fared well since Brown. Indeed many blacks have obviously excelled in both educational achievement and attainment. Moreover, many blacks have enjoyed positive labor market outcomes and have even garnered a share of power, prestige, and influence in American societyas Obama's unprecedented success in running for and being elected President of the United States so vividly illustrates. Rather, the crucial point he was flagging is that blacks in general remain grossly

Associate Professor of Philosophy and Affiliated Faculty of Law, University of Kansas. The seeds for this paper were planted during my spring 2008 law and philosophy seminar on reparations. My thanks to the outstanding group of $2 \mathrm{~L}$ and $3 \mathrm{~L}$ law students, graduate students in philosophy, and the KU faculty members that participated in this seminar. In addition to always being very stimulating, our lively exchanges about the relationship between reparations arguments and social scientific explanations of the persistence of racial inequality were instrumental in shaping and solidifying the ideas presented in this Article.

1. Benjamin CARdozo, The Nature of THE Judicial Process 81 (1921).

2. 347 U.S. 483 (1954).

3. Then-Senator Barack Obama, Remarks at CNN/YouTube Democratic Presidential Debate, Apr. 26, 2007, transcript available at $\mathrm{http}: / / \mathrm{www} . \mathrm{cnn} / 2007 / \mathrm{POLITICS} / 07 / 23 /$ debate.transcript/ (last visited Feb. 15, 2009). 
overrepresented in the ranks of underachieving students and underrepresented in the ranks of high achieving students. That point is supported by various measures of academic achievement and success including, but not limited to, $\mathrm{K}-12$ standardized test scores, grade point averages, graduation rates, and performance on college and professional school entrance exams such as the SAT and LSAT. ${ }^{4}$ As President Obama clearly understood, the existence of lower quality schools in segregated and predominately black communities is one of many competing explanations of why the racial academic achievement gap persists.

In addition to wondering why this gap persists, or more specifically, wondering how economists and other social scientists have explained the causes of this gap, students of law and philosophy, and indeed anyone concerned about the pressing problem of educational inequality in the United States, may wonder: How have this gap and empirical explanations of the relevant causes shaped the United States Supreme Court's recent jurisprudence on educational inequality in higher education in what might be described as the "post-racial" era in the United States? Furthermore, these students may wonder: What does any of this have to do with the raging public and scholarly debate over black reparations for slavery and Jim Crow? The main objective of this Article is to set the stage for a fuller treatment of these two questions by attending to Grutter v. Bollinger, ${ }^{5}$ a recent Supreme Court ruling on the constitutionality of a race-conscious law school admissions policy. ${ }^{6}$ Special attention will be paid to the Court's use of social scientific research on student body diversity in Grutter.

The Article unfolds as follows. Part II provides an overview of recent empirical data establishing the existence of racial disparities in educational achievement along with a short summary of the main explanations of the causes. Part III provides a general characterization of what might be called the "post-racial" era in the United States, along with implications for how many people think about racial discrimination

4. See infra Part II for an overview of the relevant data concerning racial disparities in educational achievement.

5. 539 U.S. 306 (2003).

6. A fuller treatment would also consider, among other things, the Court's recent ruling on race-conscious student assignment plans at the K-12 educational level. See Parents Involved in Cmty. Sch. v. Seattle Sch. Dist. No. 1, 551 U.S. 701 (2007). For an illuminating discussion of this case, which argues that the Court should have reached a different outcome, see generally Leslie Yalof Garfield, Adding Colors to the Chameleon: Why the Supreme Court Should Have Adopted a New Compelling Government Interest Test for Race-Preference Student Assignment Plans, 56 U. KAN. L. REV. 277 (2008). 
today. Part IV begins with a summary of the Supreme Court's decision in Grutter. It is then observed that this decision comports with a vital way in which the pursuit of race-conscious remedies for racial inequalities in educational achievement is seriously constrained in the post-racial era. This observation is followed by a discussion of how empirical explanations of the benefits of racial (and other forms of student body) diversity figure into Justice O'Connor's majority opinion for the Court and into Justice Thomas's dissenting opinion, with an eye toward extracting a lesson for the current public and scholarly debate over whether blacks are owed reparations for educational inequality. ${ }^{7}$ This lesson, which is presented in Part V, highlights a serious inadequacy of a prevailing normative argument for reparations - an argument that is tethered to particular social scientific explanations of the root causes of racial inequalities in education. ${ }^{8}$

The inadequacy of this argument does not require us to forego further attempts to argue that blacks are owed reparations. However, it does invite proponents of reparations to fashion alternative normative arguments that cannot be derailed by empirical disagreements over the root causes of racial inequalities in education and in other areas. While I am not suggesting that these empirical disagreements cannot be settled, it is imperative to ensure that one's normative case is not indefinitely delayed pending the outcome of such a settlement. Hence, a more promising normative argument - the development of which I must leave for another occasion - might be fittingly described as an "unscientific" argument for reparations. This argument could reach a pro-reparations normative conclusion, such as recognizing a collective societal moral obligation to improve failing public schools in segregated black neighborhoods, without being derailed by the fact that there are competing empirical explanations of why the racial achievement gap persists.

7. See generally Roy L. Brooks, AtONEMENT \& Forgiveness: A NEW MOdEL For BLACK REPARATIONS (2004) (providing an excellent treatment of this topic and a powerful argument for the pro-reparations conclusion). See also Alfred L. Brophy, RePARATIONS PRO \& CON (2006) (providing an excellent general and wide-ranging discussion of the reparations issue).

8. As I shall explain in more detail later, see infra Part V, the argument concerning reparations for educational inequality is an instance of a more general normative argument (the corrective justice argument), which has also been deployed to defend reparations for other instances of racial inequality, e.g., racial inequalities in wealth, health, housing, and matters of violence, crime, and punishment. Some of the contributors to this symposium issue provide empirical support for the existence of these inequalities. See generally Ruth D. Peterson \& Lauren J. Krivo, Race, Residence, and Violent Crime: A Structure of Inequality, 57 U. KAN. L. REV. 903 (2009); Cassia Spohn, Race, Sex, and Pretrial Detention in Federal Court: Indirect Effects and Cumulative Disadvantage, $57 \mathrm{U}$. KAN. L. REV. 879 (2009); Bruce Western \& Christopher Wildeman, Punishment, Inequality, and the Future of Mass Incarceration, 57 U. KAN. L. REV. 851 (2009). 


\section{EdUCATIONAL INEQUALITIES IN BLACK AND White}

The empirical evidence for the existence of racial disparities in educational achievement is overwhelming and compelling. It has been observed that black, Latino, and Native American children do not perform as well academically as non-Hispanic white and Asian American children. It has also been noted that urban public school children, on average, do not perform as well academically as children in suburban schools, and that low-income children, on average, do not perform as well as their middle-income and upper-income counterparts. All of these observations suggest that class is as vital as race in understanding educational achievement gaps. For present purposes I shall limit myself to highlighting some of the statistical disparities in educational achievement that pertain to the black-white achievement gap in particular. Here we find that low-income black children from urban public schools are grossly overrepresented on the short side of the racial achievement gap, and vastly underrepresented on the high side of it when considering numerous measures of educational achievement including but not limited to: grade point averages, performance on standardized tests, placement in AP, honors, and college prep courses, school suspension, school expulsion, grade promotion, and graduation rates.

Using numerous and varied data sources, social scientists have empirically tested and documented substantial disparities between blacks and whites in educational achievement at various stages of schooling, particularly in math and science, but in other subject areas as well. It is widely held that relative to white student performance, black students underachieve in school when considering various comparative measures, including comparing the performance of poor and middle class blacks to whites, and comparing the performance of blacks in urban schools to the performance of blacks in suburban schools. Moreover, these results are achieved even when controlling for a broad range of covariates, including: socioeconomic status, school quality, teacher quality, family and neighborhood characteristics, as well as levels of parental educational attainment, income, and wealth.

The first major empirical study of the black-white educational achievement gap (the Coleman Report) found that not only did racial disparities appear at every grade level, but that the gap between black and white students also widened as they advanced in age and moved up in grade level. ${ }^{9}$ Some subsequent empirical studies have substantiated

9. See James S. Coleman et al., Equality of Educational Opportunity 20 (1966); see 
these findings relying on more current data sources. For example, a recent statistical analysis report on educational achievement and blackwhite inequality, released by the National Center for Education Statistics in 2001, documents a range of statistical disparities in educational achievement between black and white children at various grade levels. The main findings, which support the 1966 Coleman Report, are that at every grade level studied, black children scored lower than white children on mathematics and reading tests. Also, in tracking the gap over time, it found that the gap (for mathematics) narrowed somewhat during elementary school, widened during junior high, and showed little change during high school. The gap in reading also differed in size depending on grade level, although not as consistently as with the mathematics gap. The Report concludes that blacks in first grade have lower math and reading scores on average than whites and that the same is true by the time they reach the twelfth grade. ${ }^{10}$

It has been suggested that things are not as bleak as they appear to be, as the racial achievement gap seems to have narrowed in recent years based on some findings. For instance, the Great City Schools Council provides evidence of convergence in the country's top urban school systems where the gap has been the most glaring. They found that racial achievement gaps in math and reading achievement in urban schools appeared to be narrowing: $55.6 \%$ of fourth grades tested and $56.4 \%$ of eighth grades tested narrowed the math achievement gap between white and black students, and $57.6 \%$ of fourth grades tested narrowed this gap at a rate equal to or faster than their states. ${ }^{11}$ In reading, $84.6 \%$ of fourth grades tested and $63.3 \%$ of the eighth grades tested narrowed the reading achievement gap between white and black students, and 58.3\% of fourth grades tested narrowed this gap at a rate equal to or faster than their states. $^{12}$

also Adam Gamoran \& Daniel A. Long, Equality of Educational Opportunity: A 40-Year Retrospective (Wis. Ctr. For Educ. Research, Working Paper No. 2006-9), available at http://www.wcer.wisc.edu/publications/workingpapers/papers.php (summarizing major developments in the literature since the publication of the Coleman Report).

10. Jonathan Jacobson et al., Educational Achievement and Black-White Inequality, NAT'L CTR. FOR EDUC. STAT. 32, 37, 42 (July 2001), available at http://nces.ed.gov/pubs2001/ 2001061.PDF.

11. Michael Casserly, Beating the Odds: A City-By-City Analysis of Student Performance and Achievement Gaps on State Assessments Results from the 2004-2005 School Year, 50th Council of the Great City Schools iv (March 2006), available at http://www.cgcs.org/images/ Publications/BTOVI.pdf.

12. Id. at $\mathrm{v}$. 
Although the Council of Great City Schools offers an encouraging report on efforts to close the racial achievement gap in the nation's top urban schools, others have cited empirical evidence to the contrary. They claim that despite considerable convergence in the racial achievement gap during most of the 1980s, since the late 1980s the gap has actually widened considerably in numerous areas including math, reading, science, and writing. ${ }^{13}$ According to other empirical findings, the widening racial achievement gap is most pronounced when comparing high achieving black students with their white peers. ${ }^{14}$ Enthusiasm about how much progress has been made in closing the racial achievement gap is further quelled by a recent statistical analysis report, Status and Trends in the Education of Racial and Ethnic Minorities, released by the National Center for Education Statistics (NCES) in 2007. The report documents a range of statistical disparities between elementary and secondary school black and white school children on different measures of academic achievement. ${ }^{15}$ While the report observes that the racial achievement gap in both reading and mathematics has decreased between 1975 and 2004, ${ }^{16}$ suggesting that public education is moving in the right direction, the most recent data clearly establishes that white students continue to outperform black students in these subject areas.

Furthermore, the NCES report highlights other worrisome trends that bear on academic achievement. For example, the report finds evidence of black-white disparities in rates of advanced coursework - such as AP or honors classes - in high school, with Asian/Pacific Islanders outperforming all other racial/ethnic groups. ${ }^{17}$ It also finds disparities in percentages of black and white students taking the SAT exam relative to their share of the population and it finds racial disparities in SAT test scores. ${ }^{18}$ According to the most recent data, in 2006, the average verbal

13. See generally Jacob L. Vigdor \& Jens Ludwig, Segregation and the Test Score Gap, in Steady Gains And Stalled Progress: Inequality and the Black-White Test SCORE GaP 181-211 (Katherine Magnuson \& Jane Waldfogel eds., 2008); Sean P. Corcoran \& William N. Evans, The Role of Inequality in Teacher Quality, in Magnuson \& Waldfogel, supra, at 212-49.

14. See Sean F. Reardon, Differential Growth in the Black-White Achievement Gap During Elementary School Among Initially High- and Low-Scoring Students 7-9 (Stanford Univ. Inst. for Res. on Educ. Pol'y \& Prac., Working Paper No. 2008-07, 2008); Eric A. Hanushek \& Steven G. Rivkin, Harming the Best: How Schools Affect the Black-White Achievement Gap, J. POL'Y ANALYSIS \& MGMT. (forthcoming).

15. See generally Angelina KewalRamani et al., Status and Trends in the Education of Racial and Ethnic Minorities, NAT'L CTR. FOR EDUC. STAT., NCES 2007-039 (Sept. 2007), available at http://nces.ed.gov/pubs2007/2007039.pdf.

16. Id. at 46,50 .

17. Id. at $64-74$.

18. Id. at 76 
score for white students was 527 while the average score for black students was 434, which puts whites at the top and blacks at the very bottom of this achievement spread. ${ }^{19}$ The data also showed the gap between their average mathematics score, which exceeded 100 points, with whites averaging 536 (second only to Asian/Pacific Islanders) and blacks averaging 429 , which still puts blacks at the very bottom of the achievement spread. ${ }^{20}$ There are also worrisome statistics regarding factors apart from grades and test performance that have obvious bearing on academic achievement. For instance, the NCES report also finds that in 2003, a higher percentage of black elementary and secondary students than white students had been suspended from school $(20 \%$ of black students and $9 \%$ of white students), retained a grade $(17 \%$ of black students and $8 \%$ of white students), or expelled (5\% of black students and $1 \%$ of white students). ${ }^{21}$ The report also found that in 2005, the dropout rate for black high school students was $10 \%$, contrasted with $6 \%$ for whites. $^{22}$

What should we make of these and other glaring statistical disparities in educational achievement between blacks and whites? More specifically, why do they persist and what is wrong with them? Responses to these last two questions have been closely connected in some of the recent literature on black reparations, particularly where we find corrective justice-based arguments for (or against) black redress for slavery and Jim Crow. ${ }^{23}$ To be sure, the mere fact of these statistical disparities in educational achievement does not tell us about their causes and it is commonplace to assume that without knowledge of these causes we cannot assess their moral significance. In particular, it is assumed that without such knowledge we cannot determine who or what is morally responsible for the existence of these disparities; we cannot determine who is morally responsible for eradicating them; and, presumably, we cannot even determine whether their persistence is objectionable from the moral point of view.

Hence, it would appear that ascertaining the empirical causes of educational inequalities is vital for our moral project of appraising them and determining the moral obligations that they generate. Yet we must take care not to presume that the close link between establishing educational policy (or interpreting law) and ascertaining the empirical

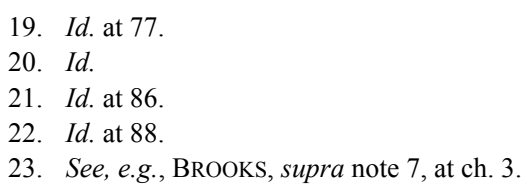


causes of educational inequality suggests that there is also a close link between normatively appraising educational inequality and ascertaining its empirical causes. Ideally, we should seek a normative appraisal of the racial achievement gap that is indifferent to the social scientific explanation of the underlying causes. I hope that the reasons for this become apparent after we consider the role of such explanations in both the diversity in higher education debate and the reparations debate.

In the meantime, social scientists studying social inequality know that they must go beyond merely positing statistical disparities in educational achievement, to defending explanations of their root causes. In addition to confirming the main empirical findings of the 1966 Coleman Report on the racial achievement gap by using more current data sources, much of the subsequent empirical work in the social sciences has sought to ascertain the underlying causes of racial disparities in education. ${ }^{24}$ Two questions have guided this scholarship: What is the best empirical explanation of the racial achievement gap? And why has this gap not disappeared (or been dramatically diminished) in view of the legal and educational policy interventions designed to close the racial achievement gap? The Supreme Court's decision in Brown is arguably the most important judicial intervention concerning education, and the No Child Left Behind Act of $2001^{25}$ is arguably the most significant federal legislative intervention concerning education in the last decade.

How have social scientists accounted for racial inequalities in education? Although I do not undertake a survey and assessment of the full range of explanations in the social science literature, it is worth listing several prevalent ones. ${ }^{26}$ In the face of heavy criticism, some scholars have argued that blacks are genetically inferior to whites and that this inferiority manifests itself in differences in their cognitive abilities to do math and science and to read and write. Others have argued that black students tend to come from non-standard family backgrounds with single parents (usually just a mother), and this

24. A good place to start for a sampling of various social scientific perspectives on this issue, with an emphasis on the racial achievement gap in test scores, is THE BLACK-WHITE TEST SCORE GAP (Christopher Jencks \& Meredith Phillips eds., 1998). For a more recent volume, see Magnuson \& Waldfogel, supra note 13.

25. No Child Left Behind Act of 2001, Pub. L. No. 107-110, 115 Stat. 1425 (2002) (codified as amended in scattered sections of 20 U.S.C.).

26. For a very useful survey of prevailing social scientific explanations of the racial gap in education, see, e.g., Roslyn Arlin Mickelson, When Are Racial Disparities in Education the Result of Racial Discrimination? A Social Science Perspective, 105 TCHRS. C. REC. 1052 (2003); Caroline Hodges Persell \& Giselle F. Hendrie, Race, Education, and Inequality, in THE BLACKWELL COMPANION TO SOCIAL INEQUALITIES 286 (Mary Romero \& Eric Margolis eds., 2005). 
manifests itself in lower levels of educational achievement than white students, who typically come from standard two-parent backgrounds. A closely related argument is that black students tend to come from homes with lower socioeconomic status which place less importance on educational achievement for a variety of reasons, including cultural ones, and as a result, black students simply do not work as hard in school or study as much as white students. In contrast, others have argued that many black students attend lower-quality and under-funded schools in crime-infested neighborhoods, and this has a detrimental impact on black academic performance. Furthermore, some scholars have argued that black, unlike white, students are subjected to racial bias in standardized testing (a common measure of academic achievement) in addition to racial bias in teacher perceptions of their abilities. Still others find that teacher expectations are greater for whites than for blacks and that these lower expectations negatively impact black student achievement, and that racial tracking and ability grouping-with blacks being largely absent in higher-level courses and disproportionately enrolled in lowerlevel ones-accounts for a large part of the racial achievement gap. Lastly, it has been argued that black students typically receive stiffer and more damaging sanctions for misbehavior in school than their white peers, which often results in more time away from the classroom during regular school hours.

Various analytical distinctions have been deployed to categorize the main explanations of the causes of racial inequality in general, and educational inequality in particular. Setting aside the so-called biogenetic explanations of the racial achievement gap advanced by the controversial book The Bell Curve, ${ }^{27}$ which has been widely challenged, ${ }^{28}$ social scientists have sought to articulate the ways in which the social environment has contributed to racial disparities in education and in other areas. The familiar structure versus behavior distinction has been captured by distinguishing between liberal and conservative explanations: liberals are taken to emphasize social factors such as "racial discrimination, low wages, inadequate schooling, [and] lack of jobs," while conservatives are taken to stress cultural and behavioral factors "such as values, attitudes, habits, [expectations,] and styles."29

27. Richard J. Herrnstein \& Charles Murray, The Bell Curve: Intelligence and ClASS STRUCTURE IN AMERICAN LIFE (1994).

28. See, e.g., Claude S. Fischer et Al., IneQuality By Design: Cracking the Bell CuRve МYTH (1996).

29. For this distinction, see William Julius Wilson, The Role of the Environment in the BlackWhite Test Score Gap, in Jencks \& Phillips, supra note 24, at 502. 
But more complex and dynamic explanations, which seek to transcend the social structure versus behavior dichotomy as being too "individualistic" on account of focusing exclusively on either attributes of individuals (behavior) or their particular social environment (structure), call attention to the social structure of inequality to explain differential group outcomes in education and in other areas. Included among the processes that embody this social structure are: "the institutional influences on mobility and opportunity; the operation and organization of schools; the mechanisms of residential racial segregation and social isolation in poor neighborhoods;... unequal access to information concerning the labor market, financial markets, apprenticeship programs, and schools;... and corporate decisions concerning the location and mobility of industries." 30

Obviously there is much at stake in how we explain the causes of group-based inequality in education, perhaps foremost of which is to discern how such explanations shape law and public policy. Earlier I raised the following question: Why has the racial achievement gap not disappeared (or been dramatically diminished) in view of various legal (Brown) and education policy (NCLB) interventions designed to close it? To be sure, some observers may contend that the gap has indeed diminished and that further narrowing is only a matter of time. Yet one could certainly contend that it has not disappeared entirely or been dramatically diminished, largely because legal and education policy has not been properly targeted to address the root causes of the racial achievement gap. It seems plausible that the societal interventions with the best chance for success at closing the racial achievement gap will be interventions that target the underlying causes identified by the best overall empirical explanation of why the racial achievement gap persists.

Although I certainly do not presume to know which public policy will have the best chance for success, and there is certainly deep disagreement about this in the social science literature as demonstrated above ${ }^{31}$ some empirical work gives us reason to assume that both past and present racial discrimination continue to play a vital causal role in accounting for the existence of racial inequalities in educational achievement and attainment. ${ }^{32}$ Even if we assume that the role of racial discrimination in determining the life prospects of blacks in America has declined significantly, it is still plausible to assume that this explanatory factor will at least be part of the best overall explanation of why the

30. Id. at 508 .

31. See sources cited supra notes 24-30.

32. See Mickelson, supra note 26 , at 1055-76. 
racial achievement gap persists. However, as I shall explain in the next section, appealing to racial discrimination as a cause of racial disparities in general - even as just one cause among many - faces serious obstacles in this post-racial era. And this observation should shape our understanding and assessment of Grutter v. Bollinger. Furthermore, it should shape our philosophical assessment of recent corrective-justice arguments for black reparations and other race-conscious social justice measures more generally.

\section{RACIAL DISCRIMINATION IN THE POST-RACIAL ERA}

Crafting a public policy or legal remedy that addresses the role of racial discrimination (even if it turns out to be a relatively small role) in creating educational and other persistent inequalities between blacks and whites has become increasingly difficult in America's contemporary post-civil rights, or as I prefer to say, post-racial era. First, many Americans believe that the United States has largely realized its dream of being a free and equal society with equal opportunity for all citizens, including black descendants of persons that endured the brutality and dehumanization of chattel slavery and American racial apartheid under Jim Crow segregation. ${ }^{33}$ Consequently, many citizens believe that a person's life prospects in the United States are no longer meaningfully determined (or hampered) by the color of their skin, but largely by the content of their character, their values, their work ethic, their success in taking advantage of opportunities, and their level of education.

Many people would say that at long last-particularly in the aftermath of electing the first African American U.S. President-we are living the American dream envisioned, and so eloquently articulated, by Dr. Martin Luther King, Jr. more than four decades ago during the historic 1963 March on Washington. Indeed it is easy to agree with one historian's recent observation that perhaps "no figure more fully embodies the notion that racial equality is a U.S. national imperative than Martin Luther King Jr." ${ }^{34}$ It is certainly true that Dr. King is also widely read as holding that civil rights reforms were not only "urgent matters of national redemption and moral regeneration that would open up a world for individual black achievement (the content of our character) beyond

33. See Douglas S. Massey \& Nancy A. Denton, American Apartheid: Segregation AND THE MAKING OF THE UNDERCLASS (1993).

34. Nikhil Pal Singh, Black is a COUNTRY: Race and the Unfinished Struggle for DEMOCRACY 3 (2004). 
the barrier of race (the color of our skin), ${ }^{, 35}$ but also that the passage and enforcement of civil rights reforms would enable the United States to live up to its normative promise by extending its cherished founding normative ideals of freedom and equality to all of its citizensparticularly those descending from individuals characterized in the infamous Dred Scott v. Sandford ${ }^{36}$ decision as being "so far inferior, that they had no rights which the white man was bound to respect . . .,"37

Another crucial and related aspect of what has been aptly called a "King-centric" "38 account of the civil rights era is the idea of shared citizenship, which is, in an important sense, post-ethnic or post-racial. ${ }^{39}$ By extending the scope and protection of universal normative ideals to include blacks, the civil rights movement - according to a widely held understanding of racial progress - brought us the final way toward being a unified people living under a common rule of law equally applied to and protecting all persons living under shared normative ideals of freedom and equality. This universalizing picture of citizenship associated with King, and characteristic of a post-racial understanding of American society, is aptly summed up by United States Supreme Court Justice Antonin Scalia as follows: "In the eyes of the government, we are just one race here. It is American."

Hence with the watershed Brown v. Board of Education decision in 1954, the formal undoing of American racial apartheid was fully underway. With President John F. Kennedy's 1961 signing of Executive Order 10925, which established a Committee on Equal Employment Opportunity and is famously remembered for invoking the phrase "affirmative action," and with President Lyndon B. Johnson's so-called

35. $I d$.

36. 60 U.S. 393 (1856), superseded by constitutional amendment, U.S. CONST. amend. XIII, XIV.

37. Id. at 407. Of course one must attend to King's anti-war stance and his work on behalf of organized labor and striking workers toward the end of his life to appreciate his doubts about whether civil rights was fully adequate to deal with other persistent legacies of black subordination, particularly wealth inequality and other forms of socioeconomic inequality.

38. Charles M. Payne, I've Got the Light of Freedom: The Organizing Tradition and THE MississipPi Freedom StrugGle 419 (1995); see also SingH, supra note 34, at 5 (following Payne's usage). Both historians offer different but equally powerful critiques of a King-centric inspired civic mythology of racial progress in post-civil rights America.

39. See, e.g., David A. Hollinger, Postethnic AmERica: Beyond Multiculturalism 171 (1995). Hollinger credits King with widening the circle of the "we" in "we the people," by affirming a national American "we." One could, of course, make a similar claim about Frederick Douglass. Id. I develop this claim about Douglass, and address some of the issues that arise when we consider the relationship between race and rights, in my recent book. See Derrick Darby, Rights, Race, AND RECOGNITION 109-41 (2009).

40. Singh, supra note 34, at 10 (citing Jeffrey Rosen, The Color-Blind Court, New RePuBLIC, July 31,1995 , at 23 ). 
Great Society reforms - the Civil Rights Act of 1964, the Voting Rights Act of 1965, and the Fair Housing Act of 1968-America had seemingly provided blacks all that they were owed after having endured the legacies of slavery and Jim Crow and having been formally excluded from free and equal citizenship in American society.

Of course there were many challenges associated with the implementation of Brown and the civil rights reforms in the face of widespread public resistance to the formal imperative of racial integration. And there were many challenges associated with making the case that realizing equal opportunity for blacks would ultimately demand not only implementing and enforcing anti-discrimination laws, but also dealing with widespread socioeconomic racial inequalities, which arguably placed blacks at a considerable disadvantage in taking full advantage of the removal of de jure barriers to equal civil and political participation in American society.

These challenges notwithstanding, the doors of American society were deemed to be fully open for all citizens to do business and make a life of their own choosing without being hampered on account of their race. From this vantage point, some critics of race-conscious social policy and legal remedies have insisted that government should not intervene to elevate, to positively assist, or to enable blacks individually or collectively from coming up short as a group, relative to whites, according to many measures of well-being, including educational achievement. Rather they argue that blacks should be left to bear the full burden of their poor choices when it comes to education, or that they be provided with various incentives, both positive and negative, to make better choices so that they can fully partake of King's American dream. This charge that poor choices are the main source of black disadvantage has typically been directed at blacks that are among the least well off. ${ }^{41}$ Moreover, it has been further argued that failure to acknowledge the impact of black choices and values on black disadvantage has served to widen the gap between blacks and whites along various measures of well-being, and has resulted in misplaced emphasis on forms of government intervention in the form of affirmative action and welfare policy, which have contributed to the problem of black disadvantage rather than solved it. ${ }^{42}$

\footnotetext{
41. See Byron M. Roth, Prescription for failure: Race Relations in the Age of SOCIAL SCIENCE 64 (1994).

42. See Charles Murray, Losing Ground: American Social Policy, 1950-1980 223 (1984); Thomas Sowell, Race And Culture 177 (1994); Shelby Steele, A Dream Deferred: THE SECOND Betrayal of BlaCK FreEdom IN AMERICA 47-48 (1998).
} 
The foregoing sketch captures the spirit of what I am calling the "post-racial" era in the United States. Here are its main characteristics: (1) affirmation of the inclusive nature of the American ideals of freedom and equality; (2) affirmation that the greatest legacy of the civil rights movement - understood from a King-centric perspective-was extending the scope of these ideals to previously excluded blacks, which resulted in a single "race" of Americans blending whites and blacks into a common nationality; and (3) affirmation that the creation of a "single" and "racially integrated" America has rendered the need for further government intervention on behalf of blacks, in particular, unnecessary and, moreover, that further intervention would not only be unfair and unconstitutional when secured at the expense of non-minorities, but that it would be detrimental to further black progress against persistent racial inequalities.

Part of what gives this post-racial outlook purchase is that old-style racism, or what has been called "Jim Crow racism," is no longer with us. ${ }^{43}$ It has been argued that the relative infrequency of overt bigotry, of segregationist demands, of public support for government-sponsored racial discrimination, and of open and widespread adherence to the belief that blacks are biologically inferior to whites, rather than marking an end to racism has instead marked a shift to a new form of racism aptly called "laissez-faire racism." 44 Aspects of this new racism are said to involve "persistent negative stereotyping of African Americans, a tendency to blame blacks themselves for the black-white gap in socioeconomic standing, and resistance to meaningful policy efforts to ameliorate U.S. racist social conditions and institutions." form of racism lies in acknowledging the persistence of disparities between blacks and whites but locating their source in black agency (that is, choices that blacks themselves make or fail to make either individually or collectively), which undermines the legitimacy of government-sponsored intervention to decrease racial disparities.

Social theorists and social scientists wishing to argue that racial discrimination is alive and well in post-racial America (though in the form of laissez-faire, not Jim Crow, racism) face a number of challenges, two of which are particularly relevant for present purposes. In addition

43. Lawrence Bobo et al., Laissez-Faire Racism: The Crystallization of a Kinder, Gentler, Antiblack Ideology, in RACIAL ATTITUDES IN THE 1990s: CONTINUITY AND CHANGE 17 (Steven A. Tuch \& Jack K. Martin eds., 1997). See also EduARdo Bonilla-Silva, Racism Without RaCistS: COLOR-BLIND RACISM AND THE PERSISTENCE OF RACIAL INEQUALITY IN THE UNITED STATES 2-3 (2d ed. 2006).

44. Bobo, supra note 43, at 17 .

45. Id. at 16 . 
to empirically demonstrating the ways in which blacks are disadvantaged relative to whites, they must establish causal links between current racial inequalities (e.g., in education) and historic racial discrimination during slavery and Jim Crow. Moreover, they must empirically demonstrate that current racial inequalities are being maintained, or in some cases even worsened, by contemporary racial discrimination. Proponents of this thesis need not hold that racial discrimination is the only factor constraining black opportunity in the modern period nor that race is as central a factor in the life chances for any given black individual as it was in the pre-civil rights era. Meeting both of these challenges, however, is particularly difficult when overt acts of racial discrimination are, on the one hand, admittedly less prevalent than before but, on the other hand, remain in the eyes of many people the only way of showing that racial discrimination operates to undermine black freedom and equality. ${ }^{46}$

Hence, the main problem for advocates of the persistence of racism thesis in the current post-racial era is not that the possibility of racial discrimination playing a vital role in accounting for the existence of racial inequalities in education and other areas is summarily dismissed. Rather, the main problem is with the burden of proof placed on persons advancing explanations for the persistence of racial inequalities that include a racial discrimination component. This burden of proof demands a particular causal accounting of racial inequalities, by establishing racist motives or racist intent, or old-style Jim Crow racism, as the basis for any statistical disparities between blacks and whites. In the absence of such proof, some people have been tempted to dismiss racial inequalities as merely the effects of agent-driven economic transactions in response to various needs, wants, liabilities, and incentives in a free market economy rather than the unhappy results of bad or racist intentions. ${ }^{47}$

Thus, the main problem is that there is no serious acknowledgement of the shift from Jim Crow to laissez-faire racism in the post-racial era. Consequently, any appeal to racial discrimination accounting for the causes of racial disparities or proscribing legal or policy decisions faces the constraint of providing evidence of racist intent or motive. Although it is widely acceptable to presume that racial disparities in education,

46. The problem of overlooking the new racism is partly due to the fact that when racism is alleged, individual acts of racial bigotry and violence are often cited as evidence of its persistence. But critics are always quick to point out that we cannot generalize from these isolated cases, even if they are more frequent than many people realize.

47. See SOWELL, supra note 42, at ch. 4. 
wealth, health, housing, and the criminal justice system are largely due to certain agent-relative factors, in the post-racial era, we cannot presume that they are due to agent-neutral factors such as racial discrimination. Any efforts to link these disparities to racial discrimination are compelled to show evidence that racial bias or motive account for the racial disparities in question.

Indeed one can find evidence of this in the courts. Consider the criminal law case, McCleskey v. Kemp, in which Warren McCleskey, a black man sentenced to death in Georgia for killing a white police officer, challenged the law as a violation of the Equal Protection Clause. ${ }^{48}$ The petitioner's defense relied upon a statistical study on death penalty cases in Georgia showing that "defendants charged with killing white victims were 4.3 times as likely to receive a death sentence as defendants charged with killing blacks." ${ }^{49}$ A five-to-four Supreme Court decision ruled against McCleskey's equal protection claim without challenging the data showing that he was at a higher risk of being put to death because of the race of his victim. ${ }^{50}$ Instead, the court set aside the statistical evidence as irrelevant in capital punishment cases unless there was proof of intentional discrimination or proof that racial bias had tainted the defendant's trial. ${ }^{51}$

In the next section, I will consider how this inflexible constraint on proving racial discrimination has also shaped the pursuit of greater equality of educational opportunity between blacks and whites in the courts. In particular, I consider how the University of Michigan School of Law sidestepped the burden of proving that past or present racial discrimination caused statistical racial inequalities between blacks and whites in adopting a race-conscious admissions policy. I shall be particularly concerned with highlighting the role of social scientific research on student diversity in the Supreme Court's ruling, as this will enable me to draw a valuable lesson for the black reparations debate in Part V.

48. 481 U.S. 279 (1987).

49. Id. at 287; see also ANGelo N. ANCheta, SCIENTIFIC EVIDENCE AND EQual Protection OF THE LAW 6 (2006).

50. 481 U.S. at 290-91; see also ANCHETA, supra note 49, at 6.

51. 481 U.S. at 294-95; see also ANCHETA, supra note 49, at 6. 


\section{EDUCATION AND THE SCIENCE OF DIVERSITY IN GRUTTER}

On the recommendation of a faculty committee, ${ }^{52}$ the University of Michigan Law School adopted a multi-criteria admissions policy calling for each applicant to be evaluated individually based on the entire admissions file, which included a personal statement, letters of recommendation, undergraduate grade point average, LSAT score, and an essay describing ways in which the applicant would contribute to the life and diversity of the Law School. ${ }^{53}$ In making clear that grades and scores were not assigned enough weight to guarantee admission in the case of high grades and scores or rejection in the case of low ones, the Law School emphasized the value of so-called "soft variables," such as the quality and content of the personal statement and essay. ${ }^{54}$ These variables were taken to provide valuable information about how potential applicants might usefully advance the Law School's general educational objectives. $^{55}$

A vital educational objective of the Law School was to "enrich everyone's education and thus make a law school class stronger than the sum of its parts." 56 The Law School maintained that achieving student body diversity, which would contribute to the intellectual life, social life, and the overall character of the Law School, was instrumental in achieving this purpose. ${ }^{57}$ Although the Law School stressed that various types of diversity considerations were weighted in the admission process, it nonetheless reaffirmed its longstanding commitment to a particular type of diversity, namely "'racial and ethnic diversity with special reference to the inclusion of students from groups which have been historically discriminated against, like African-Americans, Hispanics and Native Americans ....",58 With the adoption of this admissions policy, the Law School asserted an interest in using racial classifications to realize the educational benefits it associated with having a racially diverse student body.

52. The University of Michigan's Law School Dean charged a faculty committee in 1992 with crafting an admissions policy that complied with the Supreme Court's ruling in Regents of University of California v. Bakke, 148 U.S. 265 (1978), on the use of race in university admissions. Grutter v. Bollinger, 539 U.S. 306, 312 (2003).

53. Grutter, 539 U.S. at 315.

54. Id.

55. Id.

56. Id. (internal citation omitted).

57. See id. at 316.

58. Id. (internal citation omitted). 
Barbara Grutter, a white Michigan resident with a 3.8 GPA and 161 LSAT score, who was denied admission to the Law School, challenged the legality of this policy in 1996. Grutter subsequently filed suit in the United States District Court for the Eastern District of Michigan alleging that the Law School's admissions policy discriminated against her in violation of the Fourteenth Amendment of the Constitution. ${ }^{59}$ Agreeing with the petitioner that the policy was unconstitutional, the District Court ruled that the Law School's asserted interest in realizing the educational benefits of a racially diverse student body was not compelling, and even if it had been compelling, the policy had not been narrowly tailored to further this interest. ${ }^{60}$ On appeal, a divided United States Court of Appeals for the Sixth Circuit reversed this judgment, holding that Justice Powell's opinion in Bakke was binding precedent and established diversity as a compelling state interest. ${ }^{61}$ Moreover, it found that the Law School's use of race was indeed narrowly tailored since race was merely a "potential 'plus' factor" in a multi-criteria admissions policy. ${ }^{62}$ Upon granting certiorari, the pivotal issue brought before the United States Supreme Court in Grutter v. Bollinger was "[w]hether diversity is a compelling interest that can justify the narrowly tailored use of race in selecting applicants for admission to public universities." 63

By finding that the Law School's interest in attaining the educational benefits that flow from a diverse student body was compelling, the Court ruled by a narrow five-to-four margin that the Law School's use of race passed the compelling interest requirement of the strict scrutiny test established by the Court in Adarand Constructors, Inc. v. Pena. ${ }^{64}$ By finding that the school's policy of considering an applicant's race as a "plus" factor along with other individual academic and nonacademic factors, and by considering each applicant individually rather than merely as a member of a racial group, the Court ruled that the Law School's use of race in a highly individualized and holistic review of each applicant's file was narrowly tailored. ${ }^{65}$ The Court concluded that because the Law School's race-conscious admissions program was

59. Id. at $317-18$.

60. Id. at 321 .

61. Id. (citing Grutter v. Bollinger, 288 F.3d 732 (2002) (en banc)).

62. Id.

63. Id. at 322. See Linda S. Greene, The Constitution and Racial Equality After Gratz and Grutter, 43 WASHBURN L.J. 253, 255 n.22 (2004) (summarizing federal courts of appeals cases in which the question of whether diversity qualifies as a compelling interest is addressed).

64. Grutter, 539 U.S. at 331, 342 (citing Adarand Constructors, Inc. v. Pena, 515 U.S. 200, 227 (1995)).

65. Id. at $309,340,343$. 
narrowly tailored and asserted a compelling interest in gaining the educational benefits of student body diversity, the admissions program survived strict scrutiny as required by the Equal Protection Clause. ${ }^{66}$

Not since Bakke had the Supreme Court taken up the issue of whether using race as a criterion for admission to an institution of higher learning violated the Fourteenth Amendment. ${ }^{67}$ Although Bakke did not result in a majority opinion, Justice Powell's opinion has served as the "touchstone for constitutional analysis of race-conscious admissions policies." ${ }^{\text {"68 }}$ Given the heavy reliance on this opinion by the majority in Grutter, it is reasonable to interpret Grutter as making Powell's opinion in Bakke settled law. ${ }^{69}$ Furthermore, several insights first expressed by Powell — and later by the Grutter majority - are paradigmatic instances of judicial thought about racial discrimination in the post-racial era that embody a clear endorsement of the prevailing King-centric perspective. ${ }^{70}$ The first insight is that equal protection of the law applies to individuals (not groups), and for the protection to be truly equal it must apply to all persons (including whites) that are asked to bear a burden because of race. The second and related insight is that this understanding of equal protection proscribes any government use of race designed to reduce disadvantages suffered by historically disfavored minorities. Describing such uses as "racial balancing," Powell contends that using race to set aside positions for minorities in professional school would place undue burdens on innocent third parties "who bear no responsibility for whatever harm the beneficiaries of the special admissions program are thought to have suffered." ${ }^{71}$ A further insight, which presumably makes up for the loss incurred by restricting the scope of backward-looking or remedial justifications of race-conscious admissions policies, ${ }^{72}$ is permitting uses of race to advance a forward-looking interest in student body diversity provided that it encompasses a broader array of qualifications and characteristics of which race is but a single element. ${ }^{73}$

\footnotetext{
66. Id. at $341-42$.

67. See Regents of Univ. of Cal. v. Bakke, 438 U.S. 265, 270 (1978); see also 42 U.S.C. § 2000d (federal statute stating: "No person ... shall, on the ground of race, color, or national origin, be excluded from participation in, be denied the benefits of, or be subjected to discrimination under any program or activity receiving Federal financial assistance.").

68. Grutter, 539 U.S. at 328.

69. See id. at 344 (Ginsburg, J., concurring) (asserting that Justice Powell's opinion on use of race to further interest in diversity was not settled).

70. See id. at 344-45 (rejecting this perspective and asserting that race bias and even rank discrimination based on race continue to impede realization of our ideals).

71. Grutter, 539 U.S. at 329 (majority opinion) (quoting Bakke, 438 U.S. at 310).

72. Id. at $309-10,323$.

73. See id. at 340 (upholding an admissions program "consider[ing] race as one factor among
} 
Although all uses of race must be subject to strict scrutiny in the postracial era - and no uses can be deemed benign absent such scrutiny — not all uses of race will fail this test. Powell's opinion in Bakke and the Grutter majority allow for uses where racial diversity is part of a larger project of advancing legitimate educational objectives.

The general outlook captured by these insights is that there can be no presumption that racial disparities are due to past or current race-based discrimination against historically disfavored groups. In the post-racial era, we must allow that other factors might account for these things given the racial progress that has been made since the civil rights era and the subsequent Great Society programs. In the post-racial era, to establish that discrimination is the cause of racial disparities and to justify a raceconscious remedy one must demonstrate that there was intent or bias operating to burden someone because of race.

Given the great difficulty of establishing this finding, and not merely due to the conservative bent of the vast majority of federal judges and the majority of Supreme Court Justices, but due to the very complex and subtle ways in which race operates in contemporary America - as many social scientists have observed - the respondents in Grutter justified their race-conscious admissions policy by making an end run around race, as it were. This was accomplished by relying upon a general diversity argument, which defended a race-conscious admissions policy (though not exclusively or even principally race-conscious) as part of a larger strategy of building a more diverse student body to secure the educational benefits that flow from such diversity, including: promoting learning outcomes; better preparing law students as professionals; and better preparing law students for an increasingly diverse workforce, society, and global market place. As the Court notes, with this policy the Law School aspired to "achieve that diversity which has the potential to enrich everyone's education and thus make a law school class stronger than the sum of its parts." 74

This worthy aspiration notwithstanding, perhaps the greatest practical virtue of the Law School's strategy was skillfully adapting the justification for its policy to the Powellian insights, which reflect the current paradigm of judicial thought about racial discrimination in the post-racial era. Most importantly, the Law School made sure that the central argument for its race-conscious admissions policy-the argument that carried the day-was a forward-looking argument. It was an

many, in an effort to assemble a student body that is diverse in ways broader than race").

74. Id. at 315 (quoting the University of Michigan Law School's written admissions policy). 
argument focused not so much on historical injustice- that is, what America has done wrong to blacks and what they are owed and by whom-but focused instead on bringing about the commonly desirable good of improving educational outcomes for the benefit of law students, the Law School, and society in general. Surely, even the Justices that dissented in the case (Kennedy, J., Rehnquist, J., Scalia, J., and Thomas, J.) could appreciate the way in which this argument plays into the ideal of one nation, one race (namely, American) striving to achieve a common and positive future that does not turn on laying blame for past wrongs or historical injustices and their lingering effects.

To be sure, the Law School was well aware of the legacy of historical injustice toward racial and ethnic minorities in America. Indeed, it stressed that the admissions policy reaffirmed the Law School's longstanding commitment to "racial and ethnic diversity with special reference to the inclusion of students from groups which have been historically discriminated against, like African-Americans, Hispanics and Native Americans, who without this commitment might not be represented in [the Law School] student body in meaningful numbers." 75 Yet by making this kind of diversity just one among many types of diversity it sought to achieve, by not giving it greater or special weight and, most importantly, by not defending its policy as an effort to take affirmative action in favor of racial minorities to overcome the disadvantages and exclusions rooted in past wrongs, the Law School rendered its argument immune to the obvious objections. A backwardlooking argument in favor of a race-conscious admissions policy, namely one that defended a policy to reduce the deficit of historically disadvantaged minorities, would be deemed an unlawful instance of racial balancing and unfair to innocent third parties forced to bear the burdens of such a policy. ${ }^{76}$

Some critics of Grutter will question whether, in the final analysis, justifying the adoption of a race-conscious admissions policy as a way to achieve certain educational outcomes is better than a more direct justification of racial diversity as a way to remedy the legacy of past racial wrongs. ${ }^{77}$ And of course other critics of Grutter will question

75. Id. at 316 (quoting the University of Michigan Law School's written admissions policy).

76. These are, with slight modification, the same objections that Justice Powell raised in Bakke. See id. at 323-24 (citing Regents of Univ. of Cal. v. Bakke, 438 U.S. 265, 306-07, 310 (1978)).

77. For a thought-provoking treatment of this question, which argues that Grutter is a weaker (and hence less attractive) argument for racial diversity than the remedial argument for it in Brown, see Colin S. Diver, From Equality to Diversity: The Detour from Brown to Grutter, 2004 U. ILL. L. REV. 691, 694 (2004) (noting that "diversity is the weaker of the two arguments"). I agree with the spirit of Diver's criticism; however, it may not take adequate account of the limitations of remedial 
whether the justification for racial diversity-however indirect it may be-is nonetheless a blatant attempt to remedy past racial wrongs and is thus unlawful (in violation of the Equal Protection Clause) as well as unfair. $^{78}$ But apart from these concerns some persons who are sympathetic to the outcome of the case and the general goal of achieving a racially and ethnically diverse student body (setting aside whether it be justified on backward- or forward-looking grounds) may raise concerns about another aspect of the argument that carried the day in Grutter.

Perhaps the most striking aspect of the forward-looking argument for racial diversity in Grutter is the prominent role played by social scientific research in this argument. ${ }^{79}$ The Grutter majority not only acknowledged this role but it also gave deference to the judgment supported by this research. Justice O'Connor observes: "The Law School's educational judgment that such diversity is essential to its educational mission is one to which we defer. The Law School's assessment that diversity will, in fact, yield educational benefits is substantiated by respondents and their amici." observes: "In addition to the expert studies and reports entered into

arguments in the post-racial era. In her opinion in Grutter, Justice Ginsburg was more explicit about this limitation and offered an understanding of Brown's legacy in this light; she also embraces a strong view of what the Constitution allows in the way of redressing the effects of law-sanctioned inequality, a view that finds the Constitution much more supportive of such efforts. See Grutter, 539 U.S. at 346 (Ginsburg, J., concurring). Yet some critics (including some of her fellow Justices) will certainly take issue with her interpretation of Brown's legacy, the causes of inequality she identifies, and whether the Constitution empowers government to reduce or eradicate past effects of lawsanctioned inequality.

78. See Grutter, 539 U.S. at 374 (Thomas, J., concurring in part and dissenting in part) (arguing against the majority of the Court who apparently "believe that broader utopian goals justify the Law School's use of race" even though the "Equal Protection Clause commands the elimination of racial barriers, not their creation in order to satisfy our theory as to how society ought to be organized"” (internal citation omitted)).

79. See, e.g., Brief for American Educational Research Association et al., as Amici Curiae Supporting Respondents, Grutter v. Bollinger, 539 U.S. 306 (2003) (No. 02-241), 2003 WL 398292. This brief relied heavily upon the "Gurin Report," an expert report produced by Patricia Y. Gurin, a Professor of Psychology and Women's Studies at the University of Michigan, to demonstrate the positive effects of educational diversity. Analysis of the data lead to several major conclusions including: "“[s]tudents who experienced the most racial and ethnic diversity in classroom settings and in informal interactions with peers showed the greatest engagement in active thinking processes, growth in intellectual engagement and motivation, and growth in intellectual and academic skills." $I d$. at *5-6 (internal citation omitted). The Gurin Report found that "diversity leads to 'a learning environment that fosters conscious, effortful, deep thinking' as opposed to automatic, preconditioned responses." Id. at *6 (internal citation omitted). The Report found that diverse learning environments resulted in "more active engagement in the learning process and an increased ability to understand the perspectives of others." Id. And the Report found that " [s]tudents educated in diverse settings are more motivated and better able to participate in an increasingly heterogeneous and complex democracy ...." Id. at *7 (internal citation omitted).

80. Grutter, 539 U.S. at 328 (majority opinion). 
evidence at trial, numerous studies show that student body diversity promotes learning outcomes, and 'better prepares students for an increasingly diverse workforce and society, and better prepares them as professionals." ",81

As the amici curiae noted, Grutter would not be the first time the Supreme Court relied upon empirical evidence in an equal protection case related to race, and to determine whether promoting "educational diversity in higher education is a compelling government interest." ${ }^{\prime 82}$ In addition to being a landmark decision in Supreme Court constitutional history for taking the monumental step of dismantling racial segregation in public schools, Brown v. Board of Education is also heralded for having begun the era of reliance upon modern social scientific research in judicial decision-making. ${ }^{83}$ In footnote II of the Brown decision, which has been described as "at once the most celebrated and infamous footnote in Supreme Court history," 84 Chief Justice Earl Warren's opinion for the unanimous Court cites several social scientific studies addressing the harms of segregated schools on black children. ${ }^{85}$

Following in the footsteps of Brown, the Grutter majority also affirmed the value of social science in assessing the constitutionality of using a race-conscious policy to achieve diversity in higher education. ${ }^{86}$ But in Grutter, unlike Brown, the Court did not relegate the social scientific findings it relied upon to a footnote. ${ }^{87}$ This time, the various sources of empirical authority that were introduced in the lower courts and in amicus curiae briefs were explicitly discussed in the decision and used to support the ruling that student body diversity was a compelling interest and that the Law School admissions policy was indeed narrowly tailored, thereby surviving the strict scrutiny test and thus proving to be lawful under the Equal Protection Clause of the Fourteenth Amendment. ${ }^{88}$ While reliance upon empirical research has many virtues, including affording the decision a measure of empirical authority, it also has potential drawbacks, including concerns that the Court is not the

\footnotetext{
81. Id. at 330.

82. See Amici Curiae Brief, 2003 WL 398292, at*1.

83. ANCHETA, supra note 49 , at 2.

84. Id. at 1 .

85. Id.

86. See id. at 2 ("[T]he Grutter Court relied on multiple sources of scientific authority to support its holding.").

87. See id. ("In the fifty-plus years that have passed since the Brown decision, scientific authority has come to enjoy a prominent but no less contentious place in constitutional interpretation and the development of civil rights.").

88. Id.
} 
proper venue for screening and filtering scientific evidence speaking to such matters as whether student body diversity promotes positive educational outcomes. ${ }^{89}$

On a related note, some sympathetic critics of Brown worried that tethering the desegregation decision to the prevailing social science of the day left open the possibility that the vital decision could be undermined or even reversed by alternative social scientific research or by discrediting the empirical findings cited in Brown. ${ }^{90}$ Of course, this is precisely what happened in Brown, where the segregationists, seeking to undo the decision, not only called the empirical findings cited by Brown into question, but recruited their own social scientists and marshaled their own empirical findings to argue that a segregated learning environment would produce the best learning outcomes and that desegregated schools actually cause more harm than good, all things considered. ${ }^{91}$

By embracing an even more thorough-going commitment to empirical research findings than Brown, the Grutter Court leaves its decision vulnerable to a similar line of attack, which would draw upon alternative research findings seeking to show that diversity does not produce the claimed educational benefits or that it actually causes educational harms or causes more harm than good, all things considered. Indeed, this is precisely one of the strategies employed by Justice Thomas in his lengthy dissenting opinion, where he maintains: "The Constitution abhors classifications based on race, not only because those classifications can harm favored races or are based on illegitimate motives, but also because every time the government places citizens on racial registers and makes race relevant to the provision of burdens or benefits, it demeans us all." 92 According to Justice Thomas, "an interest in remedying general societal discrimination," or racial disparities, is a seriously inadequate justification for using racial classification. ${ }^{93}$ Indeed, such classification can only be justified, as he says, "to provide a bulwark against anarchy, or to prevent violence ... 'rising to the level of

89. See id. at 11 ("'[M]any judges may lack the technical expertise in science and mathematics that would enable them to become the types of 'amateur scientists' who could be truly effective gatekeepers.").

90. See id. at 3 ("[S]cientific authorities, if they are at all available to inform a legal dispute, can be relied upon, declared irrelevant, ignored, or even discredited by judges in a given case.").

91. See William H. Tucker, The Science and Politics of Racial Research 149 (1994).

92. Grutter v. Bollinger, 539 U.S. 306, 353 (2003) (Thomas, J., concurring in part and dissenting in part).

93. Id. 
imminent danger to life and limb.",94 Moreover, Justice Thomas has frequently insisted that when it comes to the meaning of the Equal Protection Clause we cannot distinguish between benign and suspect uses of racial classification (a point that Justice Powell emphasizes as well in Bakke, although Powell seems to allow strict judicial scrutiny to determine if a use of race is benign, whereas Justice Thomas seems to rule out all but very limited uses as benign in advance of such scrutiny). ${ }^{95}$

Setting up one of his challenges to the majority ruling in Grutter, Justice Thomas maintains: "The Court's deference to the Law School's conclusion that its racial experimentation leads to educational benefits will, if adhered to, have serious collateral consequences. The Court relies heavily on social science evidence to justify its deference." ${ }^{, 96} \mathrm{He}$ then takes issue with what he takes to be a crucial oversight. Justice Thomas contends: "The Court never acknowledges, however, the growing evidence that racial (and other sorts) of heterogeneity actually impairs learning among black students." 97 He then cites two studies, one published in the Journal of College Student Development, "concluding that black students [at Historically Black Colleges (HBCs)] experience superior cognitive development ... and that, even among blacks," the more diversity they are exposed to the more moderate the effects of attending an HBC. ${ }^{98}$ The other study, published in the Harvard Education Review, finds that blacks "attending $\mathrm{HBCs}$ report higher academic achievement than those attending predominantly white colleges." $" 99$ In addition to suggesting that racial diversity might actually impair learning among black students according to these and other studies, Justice Thomas notes that social science has not discredited the views that affirmative action "'engender[s] attitudes of [racial] superiority or, alternatively, provoke[s] [racial] resentment among those who believe that they have been wronged by" race-conscious policies. ${ }^{100}$

Hence, we see that by relying on empirical findings to support its ruling that an interest in achieving educational diversity is compelling, the Grutter majority ruling is vulnerable to Justice Thomas's attack,

\footnotetext{
94. Id. (quoting City of Richmond v. J.A. Croson Co., 488 U.S. 469, 521 (1989) (Scalia, J., concurring in the judgment)).

95. See, e.g., id. at 368 (explaining that the Equal Protection Clause prohibits all types of "classifications made on the basis of race").

96. Id. at 364 .

97. $I d$.

98. Id.

99. Id. at 364-65.

100. Id. at 373 (quoting Adarand Constructors, Inc. v. Pena, 515 U.S. 200, 241 (1995) (Thomas, J., concurring)).
} 
which challenges the decision by taking on-at least in part-the conclusiveness of the studies cited, which are at odds with the alternative empirical findings that Justice Thomas elicits. Although my present purposes do not require me to take issue with the studies that Justice Thomas cites, and I am certain that those better informed about the empirical debate on the issue would have much to say, it is nevertheless important to note that social scientists have certainly disagreed about the educational benefits of racial diversity. ${ }^{101}$ So, even if these studies are found lacking, or if Justice Thomas's use of them is unconvincing, his objection raises a real concern. What do we make of competing empirical findings that challenge the authority of the findings to which the majority in Grutter defers? As I noted earlier, there are many competing empirical explanations of the racial achievement gap and the benefits and burdens of segregated schools, and some of these explanations would undoubtedly lend support to Justice Thomas's objections. $^{102}$

We see therefore that the appeal to social science in judicial rulings comes at a cost: it opens the door to reliance on contrary empirical findings to take issue with rulings that we are otherwise sympathetic to. Of course this is not a deep objection to social science per se, as we could believe that some empirical explanations of the facts are simply incorrect, or that some are simply much better than others. Accordingly, one way to proceed in response to Justice Thomas would be to directly take on the empirical findings and conclusions that he presumes to raise against the ones relied upon by the Grutter majority. For this purpose we will certainly need much more input from social scientists. Moreover, the Court will need a reliable way to adjudicate the debate.

In the absence of a resolution to this debate, the courts must be mindful of how legal reasoning informed by particular empirical explanations is susceptible to challenges that reject the proffered explanations in favor of others. By the same token, normative political philosophers must be mindful of how prevailing normative arguments for

101. See Mickelson, supra note 26, at 1062-63 (referring to empirical literature, which argues, contrary to Justice Thomas, that desegregated schools result in better outcomes for black students).

102. Recently, some prominent social scientists have argued that, at least in the short run, diversity may be undesirable for a variety of reasons. See, e.g., Robert D. Putnam, E Pluribus Unum: Diversity and Community in the Twenty-first Century: The 2006 Johan Skytte Prize Lecture, 30 SCANDINAVIAN POL. STUD. 137, 138 (2007) ("Increased immigration and diversity are not only inevitable, but over the long run they are also desirable.... In the short to medium run, however, immigration and ethnic diversity challenge social solidarity and inhibit social capital."). I suppose that these findings might lend some support to Justice Thomas's objections; however, if, as Putnam suggests, diversity turns out to be a good thing in the long run, then the force of Justice Thomas's objection is diminished by these findings. 
reparations, which similarly rely upon empirical findings regarding the causes of racial disparities in education and in other areas, are vulnerable to similar challenges. This is the lesson that I shall now develop for the reparations debate against the backdrop of the foregoing reflections on educational inequality and the social science of racial diversity in Grutter.

\section{A LESSON FOR THE BLACK REPARATIONS DEBATE}

Black chattel slavery as practiced in the United States until slavery's demise in 1865 was a historical injustice. So too was the legacy of postslavery forced racial segregation of blacks and whites under local, state, and national law, as well as public policies that prescribed and permitted the separate and unequal treatment of blacks and whites in the public and private spheres. These historical injustices have left enduring marks on contemporary American society, foremost of which are the enduring inequalities between blacks and whites along various measures of wellbeing including but not limited to inequalities in education, wealth, health, housing, and the administration of criminal justice. ${ }^{103}$ The persistence of these empirically demonstrable racial inequalities-long after the demise of slavery and Jim Crow-has been at the center of the public debate about reparations as well as more general debates about social justice.

Consider the recent congressional hearing on bill H.R. $40^{104}$ to study slavery and its impact on American society and subsequent generations of slave descendants. This bill, which Representative John Conyers of Michigan has re-introduced every year since first proposing it in 1989, seeks to do four things: (1) acknowledge the fundamental injustice and inhumanity of slavery; (2) establish a commission to study slavery and the subsequent racial and economic discrimination against freed slaves; (3) study the impact of this legacy of discrimination on contemporary African-Americans; and (4) make recommendations to Congress on appropriate remedies to redress the harm inflicted on living African-

103. Papers in this symposium issue offer social scientific and theoretical perspectives on some of these persistent racial inequalities. See generally Ronald Caldwell Jr., The Erosion of Affirmative Action and its Consequences for the Black-White Educational Attainment Gap, 57 U. KAN. L. REV. 813 (2009); Peterson \& Krivo, supra note 8; Spohn, supra note 8; Western \& Wildeman, supra note 8.

104. Commission to Study Reparation Proposals for African-Americans Act, H.R. 40, 110th Cong. (2007). At the beginning of the 111th Congress, Representative John Conyers, Jr., of Michigan reintroduced this legislation. See Commission to Study Reparations Proposals for African-Americans Act, H.R. 40, 111th Cong. (2009). 
Americans. ${ }^{105}$ After almost two decades, this bill finally got a hearing on December 18, 2007 during a meeting of the Congressional Subcommittee on the Constitution, Civil Rights, and Civil Liberties. During this historic hearing the issue of persistent racial disparities and black disadvantage relative to whites figured prominently in some of the testimony by supporters as well as critics of the bill. ${ }^{106}$

During the hearing, Representative Conyers cited empirical data which he contended linked current racial disparities in education and in the poverty rate to the legacy of slavery: namely that the black high school drop-out rate is fifty percent compared to twenty-three percent for whites; that the national average scores in math, science and reading for black seventeen year olds are comparable to the scores for white thirteen year olds; and that the poverty rate of blacks, at twenty-four percent, is twice the national average. ${ }^{107}$ But critics of reparations rejected this explanation of the racial achievement and poverty gaps.

One critic of the bill, Roger Clegg, a former deputy in the U.S. Department of Justice's Civil Rights Division from 1987 to 1991, and president and general counsel of the Center for Equal Opportunity, a nonprofit research and educational organization in Falls Church, Virginia, testified that the proposals in H.R. 40 are an unnecessary, hopeless, and divisive task "ill-suited" for a government commission. ${ }^{108}$ During his testimony Clegg contended:

The principal hurdle facing African Americans today is the fact that seven out of [ten] African Americans are born out of wedlock. Just about any social problem that you can name - crime, drugs, dropping out of school, doing poorly in school and so forth-has a strong correlation with growing up in a home without a father. And it is very hard to argue that this problem is traceable to slavery or Jim Crow, since illegitimacy rates in the African American community began to skyrocket just at about the time that Jim Crow was starting to crumble.

105. H.R. 40, 110th Cong. (2007); H.R. 40, 111th Cong. (2009).

106. Legacy of the Trans-Atlantic Slave Trade: Hearing Before the Subcomm. on the Constitution, Civil Rights, and Civil Liberties of the House Comm. on the Judiciary, 110th Cong. (2007) [hereinafter Hearings] (hearing to discuss H.R. 40, 110th Cong. (2007)) available at http://frwebgate.access.gpo.gov//cgi-bin/getdoc.cgi?dbname=110_house_hearings\&docid=f:39707. pdf.

107. See id. I provide a more detailed account of the relevant education statistics on the racial achievement gap in Part II of this Article. For a detailed presentation of the case linking racial inequalities in education to slavery and Jim Crow segregation, see BROOKS, supra note 7.

108. Hearings, supra note 106, at 28, 30 (testimony of Roger Clegg).

109. Id. at 29 . 
Another critic, Stephan Thernstrom, Professor of History at Harvard and member of the Manhattan Institute, adopted essentially the same explanation of enduring economic disparities between whites and blacks. ${ }^{110}$ He contended:

The principal source of black poverty today, for example, is African American family structure. One-paycheck families (or zero-paycheck families who are dependent upon public assistance) are far more likely to fall into poverty than two-parent, two-paycheck families. Blaming African-American out-of-wedlock births and absent fathers upon an institution that disappeared 142 years ago makes little sense.

These critics opt for what might be called black agent-relative explanations of persistent racial disparities, namely ones that locate their root causes in the action (or inaction) of blacks themselves.

In contrast, Tommy Wells, then president-elect of the American Bar Association, was present at the hearing to indicate the ABA's support, in principle, for H.R. 40. ${ }^{112}$ In addition to citing Justice Ginsburg's concurring opinion in Grutter v. Bollinger as an authority for the claim that "rank discrimination based on race" remains alive and continues to impede the nation's realization of its highest values and ideals, Wells cited Justice Kennedy's address before the American Bar Association in 2004 as support for the persistence of racial disparities in the criminal justice system in particular. ${ }^{113}$ Furthermore he added to Kennedy's findings by noting the following:

Even though African-Americans comprise only $13 \%$ of the American population, over $44 \%$ of the 1.4 million persons incarcerated in 2003 were black[.] A report released by the Bureau of Justice Statistics found that a black male had a 1 in 3 chance of being imprisoned during his lifetime, compared to a 1 in 6 chance for a Latino male and a 1 in 17 chance for a white male. Nearly $10 \%$ of black males age 25 to 29 are incarcerated compared with $1.1 \%$ of white males in the same age group, and black females are five times more likely to be incarcerated than white females. ${ }^{114}$

\footnotetext{
110. Id. at 82-86 (testimony of Stephan Thernstrom).

111. Id. at 85 .

112. Id. at 72 (testimony of Tommy Wells).

113. Id. at $72-73$

114. Id. at 78 (citations omitted). For illuminating social scientific perspectives on racial disparities and criminal justice, see the papers in this symposium issue by Ruth Peterson and Lauren Krivo, Cassia Spohn, and Bruce Western. See Peterson \& Krivo, supra note 8; Spohn, supra note 8; Western \& Wildeman, supra note 8.
} 
To be sure, Wells admits that there is serious disagreement about the causes of these enduring racial disparities in the criminal justice system, but they certainly lend themselves to an explanation that grounds these disparities in some sort of systemic discrimination based on race. ${ }^{115}$ This is an instance of what might be called a black agent-neutral explanation of persistent racial disparities, one that locates their root causes in something other than the actions (or inactions) of black agents.

The foregoing explanations of racial inequalities in the public debate draw or rely upon empirical scholarship. Social scientists, including sociologists and economists, have compiled and analyzed data pertaining to racial disparities that now figures prominently not only in academic discussions of reparations but also in the halls of Congress and in the courts as the legislative and judicial branches of government labor to determine what - if anything further - the United States must do to come to terms with the nation's legacy of slavery and segregation. In the quotation from Justice Benjamin Cardozo, with which I began this Article, Cardozo implores the courts to view statutes not in isolation but in view of present-day conditions as revealed by the labor of economists and other social scientists. ${ }^{116}$ Everyone who shares this pragmatic outlook should certainly applaud the law's engagement with the social scientists as it seeks to understand and apply our abiding legal and normative principles to the issue of black reparations.

In this Article, I have focused on black and white inequalities in educational achievement. Although my concern has not been to connect these inequalities to the legacies of slavery and Jim Crow, others have certainly done this, as I have already noted. ${ }^{117}$ As we shall see shortly, establishing the connection between these past wrongs and persistent racial inequalities in education (and in other areas) has been vital to recent scholarly arguments for black reparations. A strong normative case can be made for reparations (provided that the nature and scope of the moral obligation is properly understood); however, making this case is beyond the scope of this Article. For now I want to raise a concern about a commonplace normative argument for black reparations-an argument that forges a strong causal link between the past wrongs of slavery and Jim Crow and present-day inequalities between blacks and

115. Hearings, supra note 106, at 79. Roslyn Arlin Mickelson also takes account of this disagreement in arguing for the primacy of the racial discrimination hypothesis. See Mickelson, supra note 26.

116. See CARDOZO, supra note 1 and accompanying text.

117. See, e.g., BROOKS, supra note 7. 
whites. $^{118}$ By calling this argument into question I aim to provide a justification for seeking an alternative normative argument for black reparations, one that is better equipped to accommodate the full sweep of empirical explanations of racial inequalities that both supporters and critics of reparations have found compelling. ${ }^{119}$

Not surprisingly, many reasonable people sharply disagree about how best to explain the widely accepted empirical facts pertaining to persistent racial inequalities between blacks and whites. ${ }^{120}$ Furthermore, many of these people disagree about how best to redress the historical injustice suffered by previous and current generations of black Americans in a liberal democratic society with a deep and abiding commitment to the normative ideals of freedom, justice, and equality. Careful consideration of the opposing arguments reveals that in many instances these empirical and normative perspectives are interrelated, such that the empirical perspectives on the root causes of ongoing racial inequalities in education, wealth, health, and crime strongly correlate with normative perspectives about what a liberal democratic society owes the racially disadvantaged. For some time now, this general relationship between empirical and normative perspectives on racial inequality has figured into scholarly and public policy debates about welfare, affirmative action, education, crime, and health care reform. But with increasing frequency it now figures into the current debate over the controversial question of whether the United States owes blacks reparations for slavery and its aftermath.

For example, within moral and legal debates about reparations we see that social science is increasingly called upon to support the claim that present-day black descendants of slaves in the United States suffer the effects of harms that are traceable to the past wrong of slavery perpetrated against their ancestors and are therefore entitled to redress. This general relationship between the empirical and the normative is

118. Although many people have offered versions of this argument, I am particularly interested in recent formulations of this argument in the emerging philosophical literature on reparations. See David Lyons, Corrective Justice, Equal Opportunity, and the Legacy of Slavery and Jim Crow, 84 B.U. L. REv. 1375 (2004); Thomas McCarthy, Coming to Terms with the Past, Part II: On the Morality and Politics of Reparations for Slavery, 32 POL. THEORY 750 (2004); and Jonathan Kaplan \& Andrew Valls, Housing Discrimination as a Basis for Black Reparations, 21 PUB. AFF. Q. 255 (2007).

119. Of course this is not to suggest that all explanations are equal in merit or are equally compelling. I certainly do not think that they are. However, this need not prevent us from crafting a philosophical normative argument that can accommodate these competing explanations.

120. In Part II, I discuss some of the disagreements over the causes of educational inequality in particular. It should be obvious that some of these causes can be generalized to apply to other kinds of inequality as well. 
salient in the corrective justice argument for black reparations, which is arguably the most common and influential normative argument for reparations. $^{121}$

The basic idea underlying the pursuit of corrective justice, a moral idea that can be traced back to Aristotle's Nicomachean Ethics, ${ }^{122}$ demands that if party A wrongfully harms party B, then A has a prima facie moral obligation to repair or make amends, so far as possible, for the wrongful harm to B. There can, of course, be debate about what exactly discharging this objection amounts to. Does it amount to A making B whole for the losses suffered? Or does it amount to A or some other party creating conditions for A and B to have good future relations despite the history and legacy of injustice between them? However we articulate the precise nature of this obligation, the general point-which seems sensible to most people - is that corrective justice demands taking concrete steps to right past wrongs. This normative ideal seems wellsuited to make the case for reparations, particularly if one accepts the presumption that previous racial disparities and black disadvantage relative to whites and current disparities are due to similar causes rooted in the past wrongs of slavery and segregation.

But various objections have been raised against applying this idea to reparations. Some critics contend that facts having to do with mixed racial ancestry and the resulting mixed racial identities make it virtually impossible to determine who is owed and who should pay reparations, pointing out possibilities in which particular blacks may owe reparations due to having slaveholding ancestors while particular whites may be owed reparations due to having slave ancestors. ${ }^{123}$ Other critics contend that if upholding justice is really at issue in corrective justice arguments for reparations, then we must consider that the passage of time can result in the normative claim for repairing past wrongs being in competition with more recent competing normative claims that preclude - on grounds of justice-taking certain reparative courses of action that will impact current or future generations. ${ }^{124}$ Perhaps the most frequently pressed objection, however, is that the perpetrators of the past wrong and its victims are long dead, in which case there are no parties that rightfully stand to benefit and none that must make amends. Some critics of

121. For more on the importance of this argument, see generally Kim Forde-Mazrui, Taking Conservatives Seriously: A Moral Justification for Affirmative Action and Reparations, 92 CAL. L. REV. 683 (2004).

122. See generally ARISTOTLE: NicomacheAn ETHICS (2d ed. Terence Irwin trans., 2000).

123. See, e.g., Chandran Kukathas, Who? Whom? Reparations and the Problem of Agency, $37 \mathrm{~J}$. SOC. PHIL. 330, 334-40 (2006).

124. See, e.g., Jeremy Waldron, Superseding Historic Injustice, 103 ETHICs 4, 14-28 (1992). 
reparations believe that this objection poses a fatal problem for defenders of black reparations, preventing them from firmly establishing that any parties are morally or legally responsible for slavery and its aftermath.

We find a version of this objection in a recent Seventh Circuit Court of Appeals decision on reparations. In this decision, the Court concluded that not only do descendants of slaves lack moral standing for any redress on corrective justice grounds but they also lack legal standing. Writing for the Court, Judge Posner puts the point this way:

$[T]$ here is a fatal disconnect between the victims and the plaintiffs. When a person is wronged he can seek redress, and if he wins, his descendants may benefit, but the wrong to the ancestor is not a wrong to the descendants. For if it were, then (problems of proof to one side) statutes of limitations would be toothless. A person whose ancestor had been wronged a thousand years ago could sue on the ground that it was a continuing wrong and he is one of the victims. ${ }^{12}$

So when applied to the historical injustice of slavery and its aftermath, the corrective justice argument is that certain parties are said to have perpetrated past wrongs against slaves and consequently have a moral and legal obligation to repair these wrongs and make the victims whole. However, the argument faces obvious objections in this form, most significantly that present-day blacks lack the moral and legal standing to be owed redress.

Defenders of reparations have not abandoned the case in view of this objection. Instead they have modified the corrective justice argument. One modification has been to focus more on past harms associated with Jim Crow racial segregation and the period immediately following the demise of segregation rather than the harms associated with slavery. ${ }^{126}$ Here the presumption is that comparisons between the actual circumstances of blacks and counterfactual ones are much less difficult if we concentrate on this more recent period of time. ${ }^{127}$ Along with this, defenders of reparations have proposed more nuanced accounts of who

125. In re African-Am. Slave Descendants Litig., 471 F.3d 754, 759 (7th Cir. 2006). Some philosophers have challenged the presumption that there can be a moral statute of limitations on rectifying injustice. See, e.g., Rodney C. Roberts, Another Look at a Moral Statute of Limitations on Injustice, 11 J. ETHICS 177 (2007).

126. Boris I. BitTKer, THE CASE FOR BlaCK REPARATIONS 93 (1973); and Emma Coleman Jordan, A History Lesson: Reparations for What?, 58 N.Y.U. ANN. SuRV. AM. L. 557, 558 (2003).

127. See Kaplan \& Valls, supra note 118, at 256-59. See also Rodney C. Roberts, The Counterfactual Conception of Compensation, 37 METAPHILOSOPHY 414, 414-28 (2006) (skeptical of counterfactual conceptions of rectificatory arguments). 
constitute the perpetrators and victims of the past wrongs, and who is ultimately responsible for righting these wrongs.

The most crucial amendment to the corrective justice argument has been to establish that descendants of slaves suffer continuing harm. For this modified version of the corrective justice argument to go through, it must be demonstrated that the past wrongs associated with slavery and its aftermath have harmed - or are continuing to harm-present-day blacks whose ancestors were slaves, so as to make clear that the victims due redress are not only those individuals that have long since died but also individuals that are living today. Within the scholarly literature on reparations the most compelling way of meeting this requirement has been to establish a causal connection between the past wrongs of slavery and racial apartheid under Jim Crow, and the current racial inequalities in which blacks are statistically overrepresented in the ranks of the worst off and underrepresented in the ranks of the better off when it comes to educational achievement, health, income, wealth, entanglements with the criminal justice system, and so on. ${ }^{128}$

So, for instance, with respect to racial disparities in health it has been recently argued:

A large gap in health exists between Blacks and Whites, and it is inextricably linked to the history of race and racism in the United States. Racial differences in SES and health are the predictable results of the successful implementation of residential segregation, a policy that was deliberately set up to create separate and unequal living conditions for Blacks. It and other aspects of racism remain central determinants of racial differences in health. Thus, the legacy of slavery and legal discrimination still matters for African Americans in the 21st century. ${ }^{129}$

Here the authors conclude that these current racial disparities in health, traceable to racial segregation, provide a basis (on corrective justice grounds) for black reparations. In the scholarly literature we also find powerful complementary arguments linking the legacy of slavery and post-slavery racial segregation to other persistent racial disparities. Some argue that housing discrimination itself, as practiced during and

128. Paying attention to these causal connections when considering the matter of reparations is not a new phenomenon. Boris Bittker made this point in his book, BITTKER, supra note 126 at 24 26. In addition to the philosophical sources of empirically-informed corrective justice arguments cited earlier, see Robert Westley, Many Billions Gone: Is it Time to Reconsider the Case for Black Reparations?, 40 B.C. L. REV. 429, 438-49 (1998).

129. David R. Williams \& Chiquita Collins, Reparations: A Viable Strategy to Address the Enigma of African American Health, 47 AM. BEHAV. SCIENTIST 977, 995-96 (2004). 
immediately after Jim Crow-setting aside the health related problemsprovides a basis for black reparations. ${ }^{130}$ Others have explored the connections between residential segregation during and after slavery in tracing the roots of educational inequalities between blacks and whites, taking the latter inequalities to provide an independent basis for black reparations. ${ }^{131}$ And yet others have examined the relationship between differential racial patterns of violence and residential racial segregation as a basis for some form of reparations. ${ }^{132}$

For those of us sharing a particular explanatory narrative regarding the history of race relations in the United States - both prior to and after the civil rights movement - this causal connection seems to be relatively obvious and does not require much effort to prove. However, for reasons that I will now sketch, establishing this causal connection between the wrongs of the past and present-day racial inequalities in education, crime, health, housing, and in other areas, is a considerably more daunting task than one might expect, especially when it comes to persuading a person to embrace a corrective justice argument for reparations who does not share our explanatory historical narrative, or our understanding of the empirical causes of persistent racial disparities. This obstacle to linking the racial wrongs of the past with current racial inequalities is endemic to the post-racial era in America.

In these newly fashioned corrective justice arguments for reparations - where the empirical meets the normative-social scientific research is called upon to establish the causal connection between past wrongs and current inequalities. The normative arguments are not only tethered to empirical findings, but to particular empirical explanations of the phenomena, say, black agent-neutral rather than black agent-relative explanations. ${ }^{133}$ Hence we find defenders of reparations challenging critics who seek to ground the causes of black disadvantage in facts about blacks themselves (e.g., propensities to engage in violent behavior or to shy away from studying and hard work) by contending:

Those who blame the victims of hypersegregation for the culture of hypersegregation are getting the causal story backward. The

130. See sources cited supra note 118.

131. See BROOKS, supra note 7.

132. See Peterson \& Krivo, supra note 8.

133. Peterson and Krivo provide a useful way of capturing the agent-neutral versus agentrelative distinction: "Taking this perspective shows how differential patterns of violence across ethnoracial groups are products of structural relations of society rather than stemming from individual differences in propensities to engage in violent behavior." Id. at 904 . This quotation is illuminating because it shows how some social scientists draw a sharp distinction between the agentneutral and agent-relative explanations. 
institutionalized, federally sanctioned and implemented discrimination that was instrumental in creating the black ghetto and the black underclass was largely the work of individual and corporate agents of the white majority, which was thereby continuing through transforming the institutionalized domination over blacks it inherited from slavery. And now, it appears, those ghettos and that underclass are selfreproducing, linked in a causal feedback loop of race and poverty. They will not disappear themselves, without the political will to repair the damages of slavery and segregation. ${ }^{134}$

Putting considerable weight on this causal story to complete the argument will not only require the input of the social sciences, it obviously makes the corrective justice argument vulnerable to critics who question the empirical findings. To be sure, some of these critics are somewhat more sensible than ones who suggest that defenders of reparations, positing such causal connections, are relying upon ideology (in a pejorative sense), not science. ${ }^{135}$ A more sensible and charitable critic might elicit empirically grounded reasons for thinking that the plight of blacks on the short side of inequalities today has much more to do with their own choices rather than older (or even newer) forms of racial discrimination. Indeed, with respect to the educational inequalities between blacks and whites discussed in Part II, some of these critics might add that black underachievement relative to whites need not be construed as evidence of black cultural dysfunction (as some less charitable critics have suggested). Instead, it could be construed as the result of very rational decision-making.

For example, according to an increasingly popular economic explanation of persistent and quantifiable racial disparities in educational achievement between black and white students, the impact of the social environment of black students-particularly racial peer group influence-on their choices is taken to be the primary empirical explanation for blacks performing poorer than whites on a variety of measures of educational achievement. ${ }^{136}$ From this vantage point race does indeed matter when it comes to understanding the racial achievement gap, but not in the way that many people think. From this

134. See McCarthy, supra note 118 , at 764 .

135. See generally DAVID Horowitz, UNCIVIL WARS: THE CONTROVERSY OVER REPARATIONS FOR SLAVERY (2002).

136. David Austen-Smith \& Roland G. Fryer, Jr., An Economic Analysis of “Acting White”, 120 Q. J. ECON. 551, 568-71 (2005); Signithia Fordham \& John U. Ogbu, Black Students' School Success: Coping with the "Burden of 'Acting White,", 18 URB. REV. 176, 177 (1986). For an important empirical assessment and criticism of this explanation, see Karolyn Tyson et al., It's Not "a Black Thing”: Understanding the Burden of Acting White and Other Dilemmas of High Achievement, 70 AM. SoC. R. 582, 583 (2005). 
economic perspective, race matters in understanding why the racial achievement gap is first and foremost a problem that stems from strategic black student choices in response to their black peers, rather than one that stems from racial discrimination or institutional racism in the delivery of education.

Hence, a more sophisticated and more charitable critic who focused on the question of whether blacks are owed reparations for educational inequality might draw on these and similar research findings to undermine an empirically-informed normative argument for reparations that embraces a black agent-neutral explanation of educational inequality. I am not interested in trying to adjudicate this disagreement here. Rather, my concern has been to highlight the fact that empirical work is called upon both to defend and challenge corrective justice arguments for reparations in both scholarly and public debates, which brings us to the main lesson of this Article.

The foregoing demonstrates that corrective justice arguments for black reparations seeking to forge a link between past wrongs and present racial inequalities are vulnerable to the kind of attack launched by Justice Thomas in Grutter. In Grutter, the Court upheld the use of race as an admissions criterion for purposes of achieving educational diversity, ${ }^{137}$ but rejected the use of race as a means of remedying past societal discrimination. ${ }^{138}$ Had it pursued this remedial strategy, the University of Michigan Law School would have been asked to demonstrate how past discrimination, understood narrowly, was operative and why it required such a remedy. ${ }^{139}$ This would have been a hard sell given the unreasonable burden placed upon parties seeking to establish racial discrimination in this post-racial era.

By opting to look forward to the benefits of racial and other kinds of student diversity, the Law School anchored its case in a particular empirical take on the educational benefits of diversity (racial and otherwise) and managed to sell the argument to the Court. But this created an opening for Justice Thomas and others not sold on the argument. It invited these critics to challenge the argument by taking issue with the Law School's empirical analysis of the educational benefits of racial diversity. Although this counterattack was underdeveloped in many respects, one can certainly imagine a much

\footnotetext{
137. Grutter v. Bollinger, 539 U.S. 306 (2003).

138. Id.

139. Some critics have argued that the Grutter Court should have adopted the stronger strategy of allowing for the use of race-conscious policies to reverse the effects of past discrimination on blacks. See Diver, supra note 77, at 694.
} 
more formidable attack being advanced along these lines. By the same token, one can also envision a much more formidable challenge being mounted against corrective justice arguments for reparations tethered to black agent-neutral explanations of the causes of racial inequality. To my mind, what makes these challenges particularly worrisome is that insofar as they are grounded in black agent-relative explanations of racial inequality, they will have considerable appeal in this post-racial era where laissez-faire racism or racism without racists prevails. ${ }^{140}$

Some scholars will contend that we should simply fight it out by showing that the competing empirical explanations relied upon by these critics are flawed, ideological, or do not provide the best explanation of the data. Alternatively, others might contend that these critics have not identified the root causes of racial inequality. These may prove to be profitable strategies and are well worth pursuing. However, philosophers, political theorists, legal scholars, and anyone else who has an interest in these matters will certainly have to leave it to the social scientists to fight this battle, though it is far from clear how we will declare a winner. In the meantime, it would be useful to have a normative argument ready at hand that is not held hostage to the outcome of this battle, that is, the battle over how to account for the root causes of the racial achievement gap and other racial inequalities.

The labor of social scientists is indispensable for fashioning an empirically-informed normative argument for what we owe those on the short side of racial inequalities. I have offered reasons for thinking that the most attractive argument may be one that is indifferent to which empirical explanations we embrace. Such an argument for reparations might be described as an "unscientific" argument for reparations. This is not to say that the argument ignores the social scientific explanations. Rather it attempts to take the full range of possibilities into consideration in accounting for why we owe what we owe, normatively speaking. This argument would stand in sharp contrast with prevailing corrective justice arguments for reparations that require a more definitive commitment to particular empirical explanations of the root causes of racial inequality.

\section{CONCLUSION}

In this Article, I have argued that corrective justice arguments for black reparations tethered to particular social scientific explanations of racial inequalities will be open to the same kind of counterattack

140. See supra Part III. 
launched by Justice Thomas against the social science-backed argument for racial diversity in Grutter. An important aspect of the corrective justice reparations argument is to establish the causal link between the past wrongs of racial slavery and segregation and current racial inequalities in education and in other areas. I suspect that many people are inclined to agree that there is some kind of relationship between the racial achievement gap and the legacies of slavery and Jim Crow, though there will certainly be much disagreement about the strength of this relationship. A rather forceful way of highlighting the connection between these past racial wrongs and the current racial achievement gap is to contend: "[A]lthough Jim Crow schools have been outlawed, black students, including middle-class black students, are still receiving a Jim Crow level of education."

It is unclear whether President Barack Obama had this strong a connection in mind when he remarked, "I think the reparations we need right here in South Carolina is investment, for example, in our schools." 142 But it seems quite clear that any effort to justify the pursuit of reparations for educational inequality on moral or legal grounds may do best to avoid tethering the normative case for reparations to racial discrimination-based empirical explanations of the causes of racial educational inequality. For in this post-racial, or post-Obama era, empirical explanations that tie black underachievement to choices that blacks make (or fail to make) when it comes to education are as popular-if not more popular-than explanations that link black underachievement to the persistence of racism in contemporary America. While I share President Obama's sentiment that addressing the racial achievement gap could be part of a broad strategy of black reparations, in this day and age the most compelling and pragmatically feasible argument for this will be one that can reach an empirically-informed normative conclusion regardless of the perspective one takes on the empirical causes of racial inequalities in education.

141. BROOKS, supra note 7 , at 84 .

142. See supra note 3 and accompanying text. 